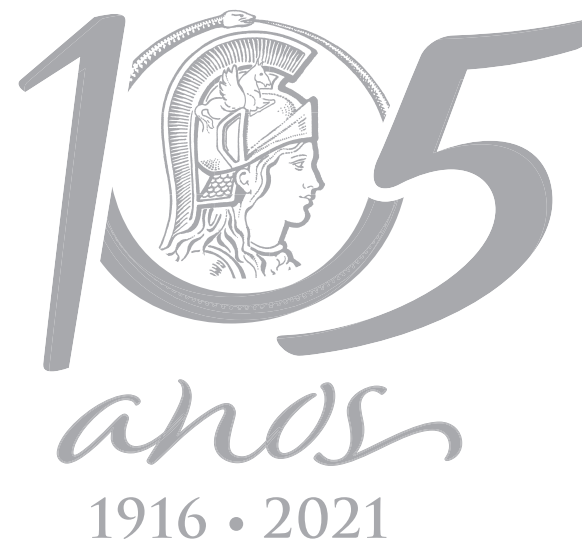

$1916 \cdot 2021$

\title{
Ants (Hymenoptera: Formicine) as Carriers of Microorganisms Indicating Hygienic and Sanitary Conditions in Urban Schools
}

\author{
CARIN GUARDA, JUNIR A. LUTINSKI, CARLA R.P.A. TEO \& MARIA A. BUSATO
}

\begin{abstract}
The presence of ants in school kitchens and canteens may pose a risk of food contamination. The present study aimed to evaluate the potential of the ants as carriers of microorganisms indicating hygienic and sanitary conditions in school kitchens and canteens in the western region of Santa Catarina. Ten samples were collected with up to ten ants in the kitchen and canteen environments in nine urban schools. The ants were evaluated using microbiological analyses regarding Staphylococcus aureus, aerobic mesophilic bacteria, total coliforms and thermotolerant coliforms/Escherichia coli. Twenty ant species were sampled. Four species presented counts for S. aureus, eight for aerobic mesophilic bacteria and three for total coliforms. The results evidenced the potential of ants as indicators of contamination and the risk of ants to carrier microorganisms in school environments and an important diversity occurring in indoor environments.
\end{abstract}

Key words: Food safety, indicator microorganisms, pest control, school community, urban ants.

\section{INTRODUCTION}

The presence of ants in school environments is important because of the potential of these insects to act as carriers of pathogenic microorganisms; which has been proven in studies already realized (Costa et al. 2006, Lise et al. 2006, Tanaka et al. 2007, Pesquero et al. 2008, Silva et al. 2012, Oliveira et al. 2017). Among the ants that occur in urban environments with the potential to carry pathogenic microorganisms, stand out Linepthema humile (Mayr, 1868) Monomorium pharaonis (Linneus, 1758), Monomorium floricola (Jerdon, 1851), Wasmannia auropunctata (Roger, 1863) and the genera Camponotus Mayr, 1861, Crematogaster Lund, 1831, Pheidole Westwood, 1840, Solenopsis spp. Westwood 1840 as to the frequency in the studies already carried out (Bueno \&
Campos-Farinha 1998, Lise et al. 2006, Garcia et al. 2011, Castro et al. 2015, Cintra-Socolowski 2015). The transportation of microorganisms occurs when the ants come into contact with contaminated sites and materials and carry them adhered to their legs and body through the environment (Bueno \& Campos-Farinha 1998, Costa et al. 2006). Anatomical characteristics such as the occurrence of hairs on the body, length, cuticle sculpture, number of specimens, amount and distribution of the exocrine glands, among others, may explain the adhesion and survival of the microorganisms in the body of the ants (Fontana et al. 2010). Due to their small size and high mobility, ants easily move around the environments through holes, cracks and crevices, normally traveling extensive areas in search of shelter and food (Peçanha et al. 2000, Costa 2007). In this search, they move through 
both contaminated and non-contaminated sites dispersing microorganisms (Peçanha et al. 2000, Tanaka et al. 2007, Simothy et al. 2018) that can contaminate food, equipment and utensils (Bueno \& Campos-Farinha 1998, Pereira \& Ueno 2008, Bragança \& Lima 2010) used in the preparation of meals in the school environment.

Another factor favoring the presence of ants in indoor environments is negligence with the presence of these insects in these places. Ants are little recognized (by people) as agents that carry microorganisms (Pereira \& Ueno 2008, Simothy et al. 2018). In general, it is neglected that ants feed on other dead animals and forage in contaminated environments and thus can carry pathogens. Thus, this disregard the risk they pose, hindering their control (Pereira \& Ueno 2008, Oliveira \& Campos-Farinha 2005).

The pathogenic microorganisms that have been reported to be carried by ants in urban environments are species of bacteria such as Enterobacteraerogenes (Kruse, 1896), Escherichia coli (Escherich, 1885), Klebisiella pneumonie (Trevisan, 1887), Pseudomonas aeruginosa (Schroeter, 1872), Staphylococcus aureus, Rosenbach, 1884 and the genera Citrobacter Werkman \& Gillen, 1932, Micrococcus Cohn, 1872 and Serratia Bizio, 1893 (Costa et al. 2006, Lise et al. 2006, Máximo et al. 2014, Menezes et al. 2015, Shahi et al. 2017).

The man acts as its main reservoir and represents a source of contamination, and can contaminate the food in different stages of the preparation, by the hands or oronasal secretions (Germano \& Germano 2008). Mesophilic microorganisms are all those capable of growing under temperatures between 35 and $37^{\circ} \mathrm{C}$ under anaerobic conditions. All food borne pathogenic bacteria are mesophilic and, therefore, a high count of these microorganisms may mean that there were conditions for the growth of pathogens. The presence of mesophilic bacteria at high counts in food is an indication of inadequate hygienic procedure in the production, processing or preservation, depending on the origin of the sample (Franco \& Landgraf 2005, Schiraldi \& De Rosa 2016).

The group of total coliforms is usually found in the environment and the count of this group is used to evaluate the hygienic conditions, because when present in high numbers indicates contamination due to inadequate cleaning or insufficient heat treatment (Forsythe 2013, Rossi et al. 2017). The detection of a high number of bacteria of the group of thermotolerant coliforms is interpreted as indicative of the presence of intestinal pathogens. E. coli is an enterobacterium commonly found in the intestines of animals and man, where it accounts for $80 \%$ of the aerobic intestinal flora. It is eliminated in feces and causes contamination of soil and water (Germano \& Germano 2008). Therefore, it is used as an indicator microorganism for fecal pollution in water, raw materials and food (Germano \& Germano 2008, Forsythe 2013).

Ants are recognized for the potential of carrying microorganisms and when they occur in food production environments, such as kitchens and canteens, can disseminate microorganisms such as S. aureus, mesophilic bacteria and coliforms that are normally found in the environment. In this context, the present study aimed to evaluate the potential of ants as carriers of microorganisms indicating hygienic and sanitary conditions in school kitchens and canteens.

\section{MATERIALS AND METHODS}

\section{Study sites}

The research was carried out in nine schools located in urban areas of four municipalities in the western region of the State of Santa Catarina, 
Chapecó, Caxambu do Sul, Guatambu and Palmitos. Four schools belong to the municipality of Chapecó, one to the municipality of Palmitos and two to each of the other municipalities.

Ten ant samples were obtained for the microbiological analyses, of which four were collected in schools in the municipalities

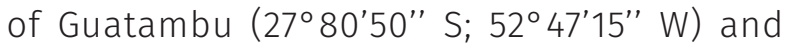

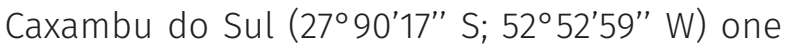
sample was collected per school evaluated in these municipalities. One sample was obtained from one school in the municipality of Palmitos

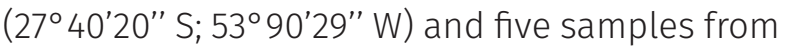
four schools in the municipality of Chapecó

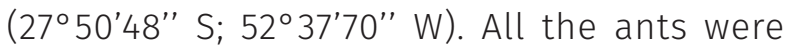
collected in kitchens and canteens, except for one school in Chapecó, where one sample was collected in the kitchen and another in the canteen. The school of Chapecó that was not sampled in the canteen is because that no ants were found foraging in the environment during collection.

The schools are characterized by a built area that varies between $677 \mathrm{~m}^{2}$ and $3000 \mathrm{~m}^{2}$. These measures were obtained in the schools, from the engineering project, during the collections. The outdoor areas range from $125 \mathrm{~m}^{2}$ to $2955 \mathrm{~m}^{2}$ and the number of trees in the garden varied between zero and 80 .

\section{Samples}

The ants were sampled in the period from September to October 2016, between 09h and 17h. Ant samples for microbiological analysis were taken through manual collection, obeying a random route in the kitchen and the canteen. All the ants sighted near the walls, on the furniture and on the floor were collected until reaching 10 ants per sample (Vieira et al. 2013). The use of baits was discarded (Oliveira \& Campos-Farinha 2005).
The ants were sampled under aseptic conditions and stored in test tubes with caps. All material used for sampling was previously sterilized. Each sample was identified with the date and place of the sample and sent to the Laboratory of Food Microbiology of the Regional Community University of Chapecó (Unochapecó) for microbiological analyses. Subsequently, the ants were returned by the laboratory for identification.

The samples identification was performed based on the identification keys proposed by Gonçalves (1961), Kempf (1964, 1965), Watkins (1976), Della-Lucia (2003), Lattke (1995), Taber (1998), Bueno \& Campos-Farinha (1999) and Fernández (2003). The classification followed Bolton (2019).

\section{Microbiological analysis}

It was decided to analyze the count of microorganisms indicating hygienic and sanitary conditions present in the sampled ants. The microorganisms evaluated in this study regarding the $\mathrm{CFU} / \mathrm{mL}$ count were $S$. aureus, aerobic mesophilic bacteria, total coliforms and thermotolerant coliforms/Escherichia coli.

The methodology used in the microbiological analyses followed the standards of the American Public Health Association (APHA 2017) and normative instruction 62 of the Ministry of Agriculture, Livestock and Supply (Brasil 2003). The analyses were performed at the Food Microbiology Laboratory of Unochapecó (report 001/2016).

\section{Environmental descriptors}

Information on school kitchens and canteens was given as follows: total area $\left(\mathrm{m}^{2}\right)$, number of cracks on the floor, number of cracks on the walls, number of openings (doors and windows), number of open food portions and number of trash cans. 


\section{Data analysis}

To present the richness found in each of the samples, a table was constructed showing the count of microorganisms present in the ants obtained in the samples (Lise et al. 2006).

The influence of the environmental factors and the number of species in the samples on the count of indicator microorganisms was tested by Pearson correlation analysis performed between the count of the indicator microorganisms present in the samples and the environmental variables. The correlations were segregated according to the significance and discarded those non-significant $(p<0.05)$.

\section{Ethical aspects}

Sampling was authorized by ICMBio (Chico Mendes Institute for Biodiversity Conservation), "Authorization for activities with scientific purpose" 54250-1 as of 08/06/2016.

\section{RESULTS}

Ant samples for analysis were composed of 20 species. The most frequent species in the samples were Nylanderia fulva (Mayr, 1862), Monomorium floricola (Jerdon, 1851), Dorymyrmex brunneus (Forel, 1908), Pogonomyrmex naegelli Forel, 1878, Pheidole lignicola Mayr, 1887 and Pheidole sp. 2. The number of species in the samples ranged from one to four (Table I).

Of the ten samples analyzed, four presented counts for S. aureus, eight for aerobic mesophilic bacteria and three for total coliforms. No samples presented counts for thermotolerant coliform/Escherichia coli (Table I).

There was a positive correlation between the counts of $S$. aureus $(\mathrm{CFU} / \mathrm{mL})$ and the number of ant species present in the samples $(r$ $=0.7, p<0.05$ ) (Figure 1).
The count of aerobic mesophilic bacteria count $(\mathrm{CFU} / \mathrm{mL})$ presented a positive correlation with the area $\left(\mathrm{m}^{2}\right)$ of kitchens and canteens $(r=$ 0.7, $\mathrm{p}<0.05$ ) (Figure 2).

\section{DISCUSSION}

The number of ant species found in this study, in the kitchen and canteen environments, is representative when compared to studies involving establishments where meals are prepared in the southern Brazil. Nylanderia fulva, M. floricola, D. brunneus, P. naegelli, P. lignicola and Pheidole sp. 2. were the most frequent in the samples. The hygienic and sanitary indicators S. aureus, aerobic mesophilic bacteria and total coliforms presented counts indicating the presence of these microorganisms in kitchens and canteens. The counts of S. aureus (CFU/mL) showed a positive correlation with the number of ant species in the kitchens and canteens. The same was observed for the area of kitchens and canteens about the count of aerobic mesophilic bacteria.

The number of ant species found in this study is similar to that observed in the nutrition sector of hospitals in southern Brazil, as pointed out by Garcia et al. (2011), who found 19 species in the nutrition sector in five hospitals and by Lutinski et al. (2015) that registered 14 species in the nutrition sector in four hospitals. Both studies were conducted in the State of Rio Grande do Sul and pointed to the nutrition sector as the most infested. Ants are attracted to the nutrition sector because of the constant availability of food, especially sugary substances and sources of proteins and oils (Bueno \& Bueno 2007, Jacobs \& Alves 2014). In schools, the canteen environment has access and movement of people, which may favor the presence of ants (Bicho et al. 2007) and explain their occurrence. 
Table I. Ant species sampled in kitchens and canteens and results of microbiological analysis of microorganisms indicating hygienic and sanitary conditions in nine schools in four cities in the western region of the State of Santa Catarina. October 2016.

\begin{tabular}{|c|c|c|c|}
\hline Samples & Ant species & Count of microorganisms & Results/CFU/mL \\
\hline \multirow[t]{4}{*}{ School1 } & Brachymyrmex sp. & Staphylococcus aureus & $1.0 \times 10^{0}$ \\
\hline & \multirow{3}{*}{$\begin{array}{l}\text { Dorymyrmex sp. } \\
\text { Pogonomyrmex naegelii Forel, } 1878 \text { and } \\
\text { Pheidole sp. } 2\end{array}$} & $\begin{array}{c}\text { Count of aerobic mesophilic } \\
\text { bacteria }\end{array}$ & $3.5 \times 10^{2}$ \\
\hline & & Count of total Coliform & $3.0 \times 10^{0}$ \\
\hline & & $\begin{array}{c}\text { Count of thermotolerant/ } \\
\text { Escherichia coli }\end{array}$ & $<1.0 \times 10^{0}$ \\
\hline \multirow[t]{4}{*}{ School2 } & \multirow{4}{*}{$\begin{array}{l}\text { Monomorium floricola (Jerdon, 1851) and } \\
\text { Pogonomyrmex naegelii Forel, } 1878\end{array}$} & Staphylococcus aureus & $1.0 \times 10^{0}$ \\
\hline & & $\begin{array}{c}\text { Count of aerobic mesophilic } \\
\text { bacteria }\end{array}$ & $1.9 \times 10^{3}$ \\
\hline & & Count of total Coliform & $<1.0 \times 10^{0}$ \\
\hline & & $\begin{array}{c}\text { Count of thermotolerant/ } \\
\text { Escherichia coli }\end{array}$ & $<1.0 \times 10^{0}$ \\
\hline \multirow[t]{4}{*}{ School3 } & \multirow{4}{*}{$\begin{array}{l}\text { Nylanderia fulva (Mayr, 1862) and } \\
\text { Solenopsis sp. } 1\end{array}$} & Staphylococcus aureus & $<1.0 \times 10^{0}$ \\
\hline & & $\begin{array}{c}\text { Count of aerobic mesophilic } \\
\text { bacteria }\end{array}$ & $1.1 \times 10^{3}$ \\
\hline & & Count of total Coliform & $<1.0 \times 10^{0}$ \\
\hline & & $\begin{array}{c}\text { Count of thermotolerant/ } \\
\text { Escherichia coli }\end{array}$ & $<1.0 \times 10^{0}$ \\
\hline \multirow[t]{4}{*}{ School4 } & \multirow{4}{*}{ Monomorium pharaonis (Linneaus,1758) } & Staphylococcus aureus & $<1.0 \times 10^{0}$ \\
\hline & & $\begin{array}{c}\text { Count of aerobic mesophilic } \\
\text { bacteria }\end{array}$ & $4.7 \times 10^{3}$ \\
\hline & & Count of total Coliform & $<1.0 \times 10^{0}$ \\
\hline & & $\begin{array}{c}\text { Count of thermotolerant/ } \\
\text { Escherichia coli }\end{array}$ & $<1.0 \times 10^{0}$ \\
\hline \multirow[t]{4}{*}{ School5 } & \multirow{4}{*}{$\begin{array}{c}\text { Dorymyrmex brunneus (Forel,190 } \\
\text { Monomorium floricola (Jerdon, 1851), Pheidole } \\
\text { pubiventris Mayr, } 1887 \text { and Solenopsis } \\
\text { saevissima (F. Smith, 1855) }\end{array}$} & Staphylococcus aureus & $4.0 \times 10^{0}$ \\
\hline & & $\begin{array}{c}\text { Count of aerobic mesophilic } \\
\text { bacteria }\end{array}$ & $7.8 \times 10^{2}$ \\
\hline & & Count of total Coliform & $1.2 \times 10^{3}$ \\
\hline & & $\begin{array}{c}\text { Count of thermotolerant/ } \\
\text { Escherichia coli }\end{array}$ & $<1.0 \times 10^{0}$ \\
\hline
\end{tabular}


Table I. Continuation

\begin{tabular}{|c|c|c|c|}
\hline School6 & \multirow{4}{*}{$\begin{array}{l}\text { Brachymyrmex coactus Mayr, 1887, } \\
\text { Camponotus sp. } 2 \text { and Pheidole sp. } 8\end{array}$} & Staphylococcus aureus & $<1.0 \times 10^{\circ}$ \\
\hline & & $\begin{array}{c}\text { Count of aerobic mesophilic } \\
\text { bacteria }\end{array}$ & $3.0 \times 10^{0}$ \\
\hline & & Count of total Coliform & $<1.0 \times 10^{\circ}$ \\
\hline & & $\begin{array}{c}\text { Count of thermotolerant/ } \\
\text { Escherichia coli }\end{array}$ & $<1.0 \times 10^{\circ}$ \\
\hline \multirow[t]{4}{*}{ School7 } & \multirow{4}{*}{$\begin{array}{c}\text { Acromyrmex subterraneus (Forel, 1893) and } \\
\text { Pheidole sp. } 2\end{array}$} & Staphylococcus aureus & $<1.0 \times 10^{\circ}$ \\
\hline & & $\begin{array}{c}\text { Count of aerobic mesophilic } \\
\text { bacteria }\end{array}$ & $4.5 \times 10^{2}$ \\
\hline & & Count of total Coliform & $3.2 \times 10^{2}$ \\
\hline & & $\begin{array}{l}\text { Count of thermotolerant/ } \\
\text { Escherichia coli }\end{array}$ & $<1.0 \times 10^{\circ}$ \\
\hline \multirow[t]{4}{*}{ School8 } & \multirow{4}{*}{$\begin{array}{l}\text { Dorymyrmex brunneus (Forel, 1908), } \\
\text { Camponotus mus Roger, } 1863 \text { and } \\
\text { Nylanderia sp. }\end{array}$} & Staphylococcus aureus & $1.0 \times 10^{0}$ \\
\hline & & $\begin{array}{l}\text { Count of aerobic mesophilic } \\
\text { bacteria }\end{array}$ & $3.0 \times 10^{0}$ \\
\hline & & Count of total Coliform & $<1.0 \times 10^{\circ}$ \\
\hline & & $\begin{array}{c}\text { Count of thermotolerant/ } \\
\text { Escherichia coli }\end{array}$ & $<1.0 \times 10^{\circ}$ \\
\hline \multirow[t]{3}{*}{ School 9/1 } & \multirow{3}{*}{$\begin{array}{l}\text { Nylanderia fulva (Mayr, 1862) and } \\
\text { Pheidole lignicola Mayr, } 1887\end{array}$} & $\begin{array}{c}\text { Staphylococcus aureus } \\
\text { Count of aerobic mesophilic } \\
\text { bacteria }\end{array}$ & $\begin{array}{r}<1.0 \times 10^{\circ} \\
2.0 \times 10^{0}\end{array}$ \\
\hline & & Count of total Coliform & $<1.0 \times 10^{0}$ \\
\hline & & $\begin{array}{c}\text { Count of thermotolerant/ } \\
\text { Escherichia coli }\end{array}$ & $<1.0 \times 10^{\circ}$ \\
\hline \multirow[t]{4}{*}{ School 9/2 } & \multirow{4}{*}{$\begin{array}{l}\text { Nylanderia fulva (Mayr, 1862), } \\
\text { Pheidole lignicola Mayr, } 1887 \text { and Wasmannia } \\
\text { sp. }\end{array}$} & Staphylococcus aureus & $<1.0 \times 10^{\circ}$ \\
\hline & & $\begin{array}{l}\text { Count of aerobic mesophilic } \\
\text { bacteria }\end{array}$ & $1.7 \times 10^{2}$ \\
\hline & & Count of total Coliform & $<1.0 \times 10^{\circ}$ \\
\hline & & $\begin{array}{c}\text { Count of thermotolerant/ } \\
\text { Escherichia coli }\end{array}$ & $<1.0 \times 10^{0}$ \\
\hline
\end{tabular}

Species of the genus Nylanderia are classified as generalists (Silvestre et al. 2003), with biological and ecological characteristics that favor the exploration of urban environments. In the interior of the buildings, the presence of $N$. fulva is associated with the propagation of microorganisms (Pesquero et al. 2008). In the present study, this species presented the highest frequency in the samples.
The genus Monomorium has a worldwide distribution (Baccaro et al. 2015). Monomorium floricola and M. pharaonis are known for their dispersal capacity and for infesting the interior of buildings (Rando et al. 2009) where they can transport microorganisms (Máximo et al. 2014). In this study, M. floricola was frequently found in school kitchens and canteens. 


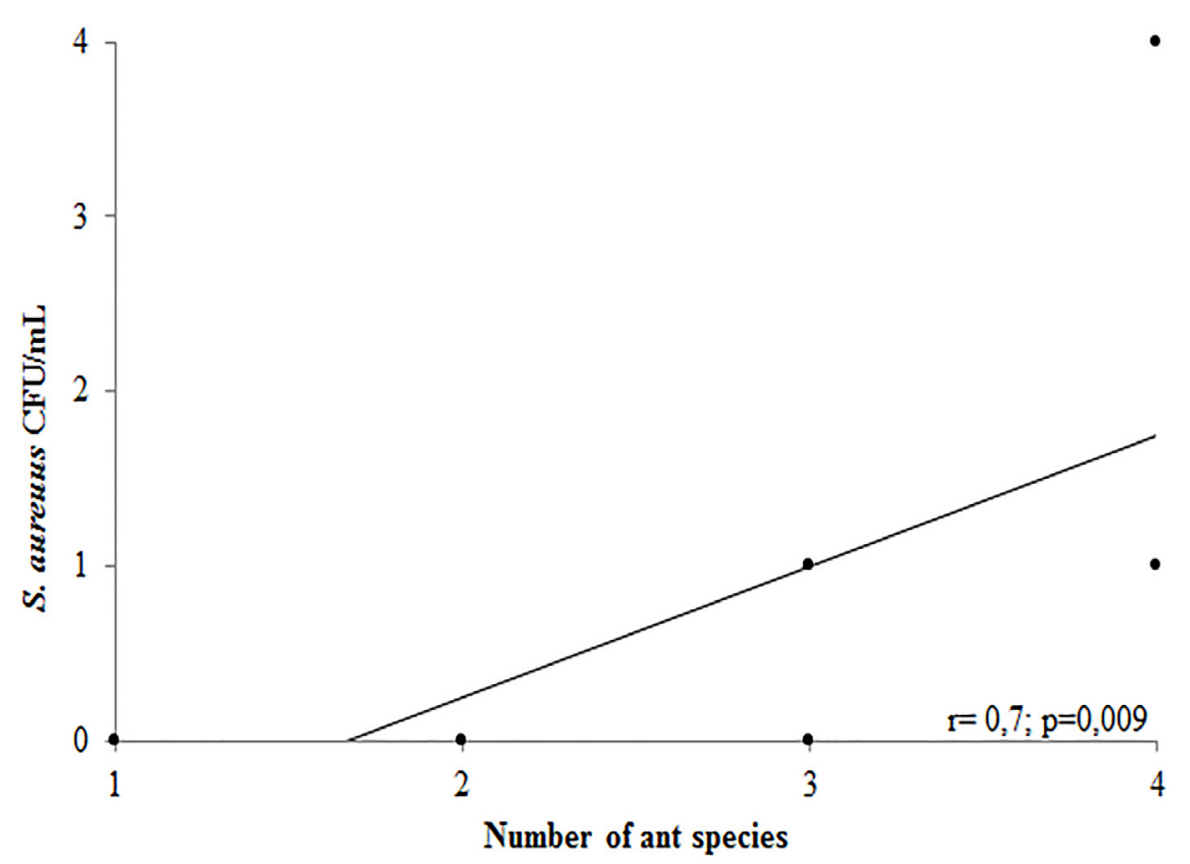

- Figure 1. Correlation between the number of ant species sampled in kitchens and canteens of schools in cities in the western region of the State of Santa Catarina and the counts of $S$. aureus CFU $/ \mathrm{mL}$. September and October 2016.

Ants of the genus Dorymyrmex are classified as generalists (Silvestre et al. 2003) and can carry microorganisms inside buildings (Máximo et al. 2014). Dorymyrmex brunneus is often found in urban environments (Feitosa et al. 2015, Lutinski et al. 2017), and was one of the most frequent in samples collected in kitchens and canteens in this study.

Pheidole presented the largest number of species in the samples. This genus is known for its great diversity in the Neotropical region. Its species are considered opportunistic, with a large capacity for territorial expansion (Bueno \& Bueno 2007). In habitats, species of this genus take advantage of structural flawslike cracks and crevices in walls and floors to build their nests. The transportation of S. aureus, E. coli, Pseudomonas aeruginosa, S. epidermidis, E. coli was already described (Costa et al. 2006, Gonçalves et al. 2011).

Ants of the genus Camponotus occur in environments with structural flaws due to poor conservation of buildings. In the interior of buildings, ants of this genus are attracted to places with foods (Baccaro et al. 2015, Ogba et al. 2017), such as kitchens, canteens and places with the presence of residues. They can act as carriers of microorganisms such as Enterococcus sp., Staphylococcus sp. Klebsiella sp., Aeromonas sp. and E. coli (Lise et al. 2006, Ogba et al. 2017).

Solenopsis ants construct their nests in parks, gardens, squares, backyards of houses, preferring places with sunlight incidence. They are often found in urban environments where they can infest (Baccaro et al. 2015). Its presence inside the buildings was associated with the transportation of bacteria such as Staphylococcus spp., Bacillus spp., S. epidermidis, Pseudomonas spp. and Enterobacterium in the works conducted by Lise et al. (2006), Fontana et al. (2010), Gonçalves et al. (2011) and Simothy et al. (2018).

The presence of Camponotus, Solenopsis and Wasmannia Forel 1893 in school environments deserves attention due to the potential that some species of these genera have of causing accidents, discomfort and burning sensation or 


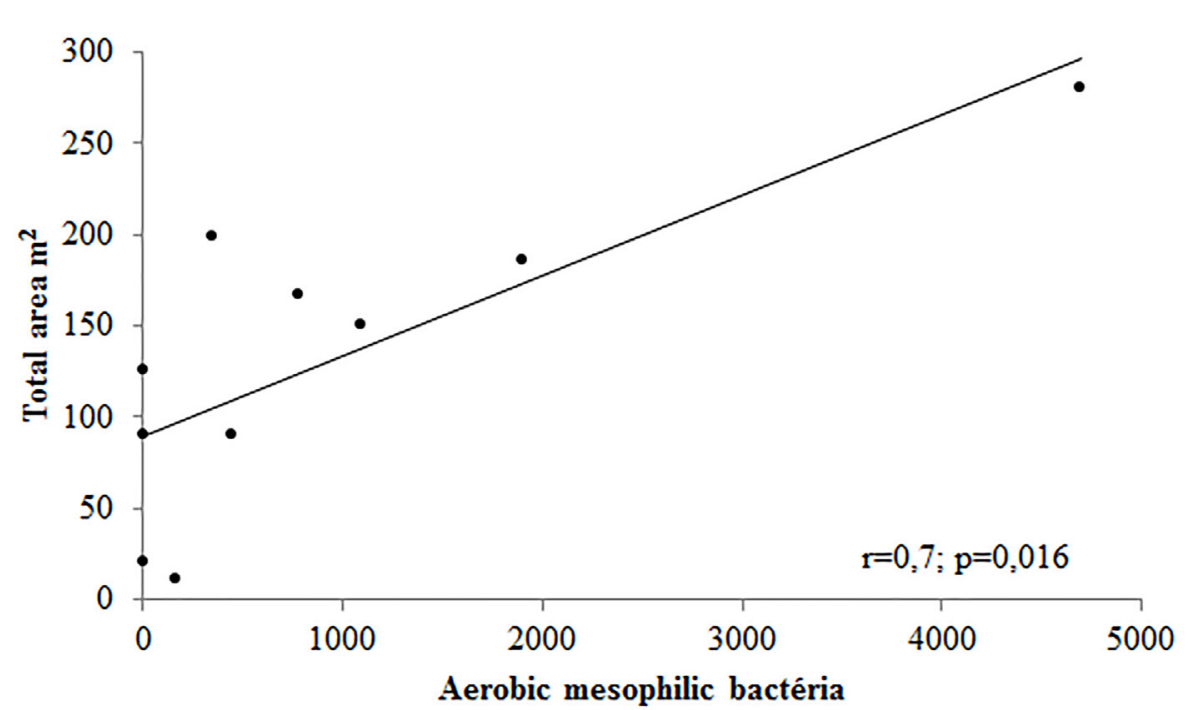

Figure 2. Correlation between the size of the built area of the kitchens and canteens and the count of aerobic mesophilic bacteria (CFU/ $\mathrm{mL}$ ) present in the ant species occurring in schools in the western region of the State of Santa Catarina. September and October 2016.

even allergic reactions (Bueno \& Bueno 2007), increasing the risk for the school community.

The occurrence of ants of the genus Pogonomyrmex inside school environments may be considered accidental. Ants of this genus feed mainly on seeds (Feitosa et al. 2015). The same is valid for the presence of Acromyrmex in the samples. This ant feeds on fungi, being rarely found inside the buildings (Bicho et al. 2007). Ants of the genus Brachymyrmex are cited as rare inside buildings, with limited presence to external areas and gardens (Oliveira \& CamposFarinha 2005). The presence of these ants in the samples can be explained by the food supply and availability of access found mainly in the canteen environment.

Dorymyrmex brunneus, Camponotus spp., M. floricola, M. pharaonis, N. fulva, Pheidole spp., Solenopsis spp. and $W$. auropunctata stand out among the species with the potential to carry pathogenic microorganisms in the studies already carried out (Lise et al. 2006, Bueno \& Campos-Farinha 1998, Garcia et al. 2011, Castro et al. 2015). In this study, these species were associated with the transportation of indicator microorganisms, such as S. aureus, aerobic mesophilic bacteria and total coliforms.
Staphylococcus aureus is a bacterium with sanitary importance Santos et al. (2007) due to the health risks that it offers and can cause intestinal disorders (Forsythe 2013). It is the species of major medical interest because it is considered the main etiological agent of community and hospital infections (Fracarolli et al. 2017).

The human being is its main reservoir, where it is often found in the skin and nasal tract of healthy people. From there, they contaminate the hands (Forsythe 2013) that become a source of contamination for food when not properly sanitized. Food poisoning caused by this microorganism is due to the contamination of food by the enterotoxins produced by the bacterium (Puah et al. 2016). These toxins are thermostable and can remain in the food even after cooking. In the kitchens and canteens, the ants can carry S. aureus in the environments and increase the risk of contamination caused by this microorganism.

Mesophilic bacteria form a group capable of multiplying between 10 으 and 45 으; the ideal temperature is around 30 으. This group includes most of the contaminants of food of animal origin, and can reach high counts when the 
food is left at room temperature. The mesophilic microorganisms provide information on the hygienic and sanitary characteristics of the processing and storage of the product (VidalMartins et al. 2005, Schiraldi \& De Rosa 2016). All foodborne pathogenic bacteria are mesophilic and a high number of these microorganisms indicates that food is unhealthy (Landgraf 2008). Ants can act in the propagation of mesophilic bacteria and the presence of these insects in kitchens and canteens can contribute to the dispersion of these bacteria in the environment and to the occurrence of contamination.

The presence of bacteria from the coliform group, whose habitat is the intestinal tract of humans and other animals, indicates environmental and fecal contamination of the product (Motta \& Belmont 2000). The number of total coliforms is used to evaluate the hygienic conditions, because, when present in high numbers, they indicate contamination due to failure in processing, poor cleaning or insufficient heat treatment (Rossi et al. 2017). In school kitchens and canteens, ants can carry the total coliforms and contribute to the dispersion of these microorganisms in the environment compromising local hygiene and food safety.

The E. coli is also an indicator of fecal contamination. The transmission of E. coli by ants was identified by Costa et al. (2006) and Simothy et al. (2018). However, in this study, there were no counts of thermotolerant coliforms and E. coli in the analyzed samples.

The microorganisms found in the ant samples of this study call attention to the risk of food contamination that the presence of the ants in the school kitchens represents for the school community. In the search for food, the ants forage in different environments, thus being able to acquire microorganisms in contaminated sites and disperse them adhered to their body and where they pass (Pesquero et al. 2008, Simothy et al. 2018). The probability of a single ant specimen carrying a given opportunistic and/or pathogenic microorganism is relatively low; however, the risk increases with the frequency of ants (Fontana et al. 2010).

Characteristics such as small size and great mobility, normally traveling in large areas in search of food, often foraging in contaminated sites, make ants excellent carriers of pathogenic microorganisms (Costa et al. 2007, Fontana et al. 2010, Simothy et al. 2018), which explain the positive correlation between the area of kitchens and canteens and the count of mesophilic bacteria.

Anatomical traits peculiar to the exoskeleton of ants, such as the occurrence or not of hairs on the body, length, sculpture of the cuticle, the number, quality and distribution of the exocrine glands, could explain the adhesion and survival of the microorganisms on their body (Fontana et al. 2010). The particular anatomical and ecological characteristics of each species may explain the positive correlation between the highest number of species and the count of $S$. aureus found in this study.

Three groups of indicator microorganisms were identified in the ant samples: S. aureus, mesophilic bacteria and total coliforms, and also, an expressive number of ants circulating in the school kitchens and canteens. The results contribute to know the microorganism-carrier potential of ants at schools and serve as an alert to managers. The study reaffirms the need for insect control in schools and biosecurity in environments where meals are prepared and distributed.

\section{REFERENCES}

APHA AMERICAN PUBLIC HEALTH ASSOCIATION. 2017. Standard Methods For The Examination of Water and Wastewater. Washington, $100 \mathrm{p}$. 
BACCARO BB, FEITOSA RM, FERNANDEZ F, FERNANDES IO, IZZO TJ, SOUZA JLP \& SOLAR R. 2015. Guia para gêneros de formigas no Brasil, 1a ed., Manaus: INPA, 388 p.

BICHO CL, BRANCÃO MLC \& PIRES SM. 2007. Mirmecofauna (Hymenoptera, Formicidae) em hospitais e postos de saúde no município de Bagé, RS Arq Inst Biol 74(4): 373-377.

BOLTON B. 2019. Synopsis and classification of Formicidae, Gainesville, USA: Memoirs of the American Entomological Institute, $370 \mathrm{p}$.

BUENO OC \& BUENO FCB. 2007. Controle de formigas em áreas urbanas, p. 68-77. In Pinto AS, Rossi MM and Salmeron E. Manejo de Pragas Urbanas. Piracicaba, CP2, 208 p.

BUENO OC \& CAMPOS-FARINHA AEC. 1998. Formigas urbanas: Comportamento das espécies que invadem as cidades brasileiras. ABCVP 1(2): 13-16.

BUENO OC \& CAMPOS-FARINHA AEC. 1999. As formigas domésticas, p. 136-180. In Mariconi FAM (Org). Insetos e outros invasores de residências. Piracicaba, FEALQ, 460 p.

BRAGANÇA M \& LIMA J. 2010. Composição, abundância e índice de infestação de espécies de formigas em um hospital materno-infantil de Palmas, TO. Neotrop Entomol 39(1): 124-130.

BRASIL. 2003. Instrução Normativa no 62. Dispõe sobre Métodos Analíticos Oficiais para Análises Microbiológicas para Controle de Produtos de Origem Animal e Água. Ministério da Agricultura Pecuária e Abastecimento. Secretaria de Defesa Agropecuária: Brasília, DF, 26 ago. de 2003. Data base acessivel em: https://www.defesa. agricultura.sp.gov.br/legislacoes/instrucao-normativasda-62-de-26-08-2003,665.html.

CASTRO MM, PREZOTO HHS, FERNANDES EF, BUENO OC \& PREZOTO F. 2015. The ant fauna of hospitals: advancements in public health and research priorities in Brazil. Rev Bras Entomol 59(1): 77-83.

CINTRA-SOCOLOWSKI P, MALASPINA O, CAVALCANTE RS, MONDELLI AL \& BUENO OC. 2015. Integrated pest management programme in hospital environment. Indoor Built Environ 24(3): 1-8.

COSTA NA. 2007. Controle de pragas em hospitais, p. 152156. In Pinto AS, Rossi MM and Salmeron E. Manejo de Pragas Urbanas. Piracicaba, CP2, 208 p.

COSTA SB ET AL. 2006. Formigas como vetores mecânicos de microrganismos no Hospital Escola da Universidade Federal do Triângulo Mineiro. Rev Soc Bras Med Trop 39(6): 527-529.
DELLA-LUCIA TMC. 2003. Hormigas de importância econômica em la región Neotropical, p. 337-349. In Fernández F. Introducción a las Hormigas de la región Neotropical. Bogotá: Instituto de Investigación de Recursos Biológicos Alexander von Humboldt, 424 p.

FEITOSA RM. 2015. Formigas do alto Tietê - Parte II, p. 101437. In Suguituru SS, Morini MSC, Feitosa RM and Silva RR. (Org). Formigas do alto Tietê. São Paulo: Canal 6, 458 p.

FERNÁNDEZ F. 2003. Introducción a las Hormigas de la región Neotropical. Bogotá, Instituto de Investigación de Recursos Biológicos Alexander von Humboldt, 424 p.

FONTANA R, WETLER RMC, AQUINO RSS, ANDRIOLI JL, QUEIROZ GRG, FERREIRA SL, NASCIMENTO ICDO \& DELABIE JHC. 2010. Disseminação de bactérias patogênicas por formigas (Hymenoptera: Formicidae) em dois hospitais do nordeste do Brasil. Neotrop Entomol 39(4): 655-663.

FORSYTHE SJ. 2013. Microbiologia da segurança dos alimentos. Porto Alegre, Artemed, 2 ed, 607 p.

FRACAROLLI IFL, OLIVEIRA SA \& MARZIALE MHP. 2017. Colonização bacteriana e resistência antimicrobiana em trabalhadores de saúde: revisão integrativa. Acta Paul Enferm 30(6): 651-657.

FRANCO BDGM \& LANDGRAF M. 2005. Microbiologia de alimentos. São Paulo, Atheneu, 182 p.

GARCIA FRM, AHLERT CC, FREITAS BR, TRAUTMANN MM, TANCREDO SP \& LUTINSKI JA. 2011. Ants (Hymenoptera: Formicidae) in Five hospitals of Porto Alegre, Rio Grande do Sul State, Brazil. Acta Sci Health Sci 33(2): 303-209.

GERMANO PML \& GERMANO MIS. 2008. Vigilância sanitária dos alimentos: qualidade das matérias-primas, doenças transmitidas por alimentos, treinamento de recursos humanos. Barueri, Manole, 986 p.

GONÇALVES CR. 1961. O Gênero Acromyrmex no Brasil. Stud Entomol 4: 113-180.

GONÇALVES MG, LOECK AE, SILVA EJE, SILVA WP, ROSADO JLO, BASTOS CP \& BASSANI MT. 2011. Associação entre formigas (Hymenoptera: Formicidae) e bactérias patogênicas em cinco hospitais do município de Pelotas, RS. Arq Inst Biol 78(2): 287-295.

JACOBS C \& ALVES IAA. 2014. Identificação de microrganismos veiculados por vetores mecânicos no ambiente hospitalar em uma cidade da região noroeste do estado Rio Grande do Sul. Rev Epidemiol Controle Infecç 4(4): 238-242.

KEMPF WW. 1964. A revision of the Neotropical fungusgrowing ants of the genus Cyphomyrmex Mayr. Part 1: Group of strigatus Mayr. Stud Entomol 7(1): 1-44. 
KEMPF WW. 1965. A revision of the Neotropical fungusgrowing ants of the genus Cyphomyrmex Mayr. Part II: Group of rimosus (Spinola) (Hym., Formicidae). Stud Entomol 8: 161-200.

LANDGRAF M. 2008. Microrganismos indicadores, cap. 3, p. 27-32. In Franco BDGM and Landgraf M (Eds). Microbiologia dos alimentos. São Paulo, Atheneu, 182 p.

LATTKE J. 1995. Revision of the ant genus Gnamptogenysinthe New World (Hymenoptera: Formicidae). J Hymenopt 4: 137-193.

LISE F, GARCIA FRM \& LUTINSKI JA. 2006. Association of ants (Hymenoptera: Formicidae) with bacteria in hospitals in the State of Santa Catarina. Rev Soc Bras Med Trop 39(6): 523-526.

LUTINSKI JA, AHLERT CC, FREITAS BR, TRAUTMANN MM, TANCREDO SP \& GARCIA FRM. 2015. Ants (Hymenoptera: Formicidae) in hospitals of southern Brazil. Rev Colomb Entomol 41(2): 235-240.

LUTINSKI JA, GUARDA C, LUTINSKI CJ \& GARCIA FRM. 2017. Formigas em ambientes urbanos no Sul do Brasil. In: Bueno OC, Campos AEC and Morini MSC (Org). Formigas em ambientes urbanos no Brasil.1 ed. São Paulo, Canal 6 editora, p. 397-422.

MOTTA MRA \& BELMONT MA. 2000. Avaliação microbiológica de amostras de carne moída comercializada em supermercados da região Oeste de São Paulo. Hig Aliment 11(78/79): 59-62.

MÁXIMO HJ, FELIZATTI HL, CECCATO M, CINTRA-SOCOLOWSKI P \& BERETTA AL. 2014. Ants as vectors of pathogenic microorganisms in a hospital in São Paulo county, Brazil. BMC Res Notes 7(554): 1-5.

MENEZES JS, LIMA LS, MOREIRA BS, LOIOLA CF \& CHAVASCO K. 2015. Análise microbiológica de formigas capturadas em ambiente hospitalar da cidade de Alfenas-MG. Rev Univ Vale Rio Verde 13(1): 589-598.

OGBA OM, AKPAN AA, OLORODE OA \& BASSEY YBO. 2017. The public health importance of the association between Componotus consobrinus and potential bacterial pathogens in human dwellings. JMEN 5(7): 1-4.

OLIVEIRA BRM, SOUSA DE LF, SOARES RC, NASCIMENTO TC, MADUREIRA MS \& FORTUNA JL. 2017. Ants as Vectors of Bacteria in Hospital Environments. J Microbiol Res 7(1): $1-7$.

OLIVEIRA MF \& CAMPOS-FARINHA AEC. 2005. Formigas urbanas do município de Maringá, PR, e suas implicações. Arq Inst Biol 72(1): 33-39.
PEÇANHA MP, CAMPOS-FARINHA AEC, BUENO OC, LEITE CQF, SUMI DV, CASTILHO MAA, SILVA FM \& CARROCCI AM. 2000. Formigas como vetor de propagação de resistência bacteriana em hospitais Universitários. Rev Inst Med Trop São Paulo 42: 84-86.

PEREIRA RS \& UENO MO. 2008. Formigas como veiculadoras de microrganismos em ambiente hospitalar. Soc Bras Med Trop 41(5): 492-495.

PESQUERO MA, FILHO JE, CARNEIRO LC, FEITOSA SB, OLIVEIRA MAC \& QUINTANA RC. 2008. Formigas em ambiente hospitalar e seu potencial como transmissoras de bactérias. Neotrop Entomol 37(4): 472-477.

PUAH SM, CHUA KE \& TAN JAMA. 2016. Virulence Factors and Antibiotic Susceptibility of Staphylococcus aureus Isolates in Ready-to-Eat Foods: Detection of S. aureus Contamination and a High Prevalence of Virulence Genes. Int J Environ Res Public Health 13(199): 1-9.

RANDO JSS, MATSUMOTO LS, SILVA GV, QUIRINO AFA \& HADDAD RE. 2009. Caracterização da mirmecofauna em estabelecimentos ligados à área da saúde no município de Bandeirantes, PR. Arq Inst Biol 76(4): 665-671.

ROSSI EM, BEILKE L \& BARRETO JF. 2017. Microbial contamination and good manufacturing practices in school kitchen. J Food Saf 38(1): 1-9.

SANTOS AL, SANTOS DO, FREITAS CCF, FERREIRA BLAF, AFONSO IF, RODRIGUES CR \& CASTRO HC. 2007. Staphylococcus aureos: visitando uma cepa de importância hospitalar. J Bras Patol Med Lab 43(6): 413-423.

SCHIRALDI C \& DE ROSA M. 2016. Mesophilic organisms. In: Drioli E and Giorno L (Eds). En-cyclopedia of Membranes. Springer Berlin Heidelberg, Berlin, Heidelberg, p. 1-2.

SHAHI M, DAVOODIAN P, ANSARI M, GHAZI F \& AKBARZADEH K. 2017. Synanthropic Ants as Vectors of Pathogens in Hospitals of Iran. JKMU 24(6): 498-504.

SILVA GM, CARMO MS, MORAES LS, MORAES FC, BARNABÉ AS \& FIGUEIREDO PMS. 2012. Formigas (Hymenoptera: Formicidae) como vetores de bactérias em ambiente hospitalar na cidade de São Luis - Maranhão. Rev Patol Trop 41(3): 348-355.

SILVESTRE R, BRANDÃO CRF \& SILVA RR. 2003. GrupoS funcionales de hormigas: el caso de los grêmios del Cerrado, p. 113-148. In Fernández F (Ed). Introducción a las hormigas de la región neotropical. Bogotá: Instituto de investigación de recursos biológicos Alexander von Humboldt, 424 p.

SIMOTHY L, MAHOMOODALLY F \& NEETOO H. 2018. A study on the potential of ants to act as vectors of foodborne pathogens. Microbiology 4(2): 319-333. 
TABER SW. 1998. The world of the harvester ants. College Station, Texas A \& M University Press, 213 p.

TANAKA AJM, VIGGIANI AMFS \& PERSON OC. 2007. Bactérias veiculadas por formigas em ambiente hospitalar. Arq Méd ABC 32(2): 60-63.

VIDAL-MARTINS AMC, ROSSI-JUNIOR OD \& RESENDE-LAGO NC. 2005. Microrganismos heterotróficos mesófilos e bactérias do grupo do Bacillus cereus em leite integral submetido a ultra alta temperatura. Arq Bras Med Vet Zootec 57(3): 396-400.

VIEIRA GD, ALVES TC, SILVA OB, TERASSINI FA, PANIÁGUA NC \& TELES CBG. 2013. Bactérias Gram positivas veiculadas por formigas em ambiente hospitalar de Porto Velho, Estado de Rondônia, Brasil. Rev Pan-Amaz Saúde 4(3): 33-36.

WATKINS JF. 1976. The identification and distribution of New World army ants Dorylinae: Formicidae). Markham Press Fund of Baylor University Press. Waco, 102 p.

\section{How to cite}

GUARDA C, LUTINSKI JA, TEO CRPA \& BUSATO MA. 2021. Ants (Hymenoptera: Formicine) as Carriers of Microorganisms Indicating Hygienic and Sanitary Conditions in Urban Schools. An Acad Bras Cienc 93: e20190713. DOI. 10.1590/0001-3765202120190713.

Manuscript received on June 26, 2019;

accepted for publication on December 10, 2019

\section{CARIN GUARDA}

https://orcid.org/0000-0003-4323-5080

\section{JUNIR A. LUTINSKI}

https://orcid.org/0000-0003-0149-5415

CARLA R.P.A. TEO

https://orcid.org/0000-0002-1534-6261

\section{MARIA A. BUSATO}

https://orcid.org/0000-0003-0043-7037

Programa de Pós-Graduação em Ciências da Saúde, Universidade Comunitária da Região de Chapecó/ UNOCHAPECÓ, Av. Senador Attílio Fontana, 591-E, Efapi, Caixa Postal 1141, 89809-000 Chapecó, SC, Brazil

Correspondence to: Junir Antonio Lutinski

E-mail: junir@unochapeco.edu.br

\section{Author contributions}

Carin Guarda: Research conception, sampling, laboratory tests, writing of the manuscript and and final review. Junir A. Lutinski: Research conception, sampling, statistical analysis, writing of the manuscript and final review. Carla R.P.A. Teo and Maria A. Busato Research conception, writing of the manuscript and final review.

\section{(c) $B Y$}

